\title{
THE INFLUENCE OF WORKLOAD AND MOTIVATION ON EMPLOYEE SATISFACTION AND PERFORMANCE OF PT GEMA SOERYA SAMODRA
}

\author{
Teddy Adrianto ${ }^{1}$, Zainal Ilmi ${ }^{2}$, Ariesta Heksarini ${ }^{3}$ \\ 1,2,3 Faculty of Economics and Business, University of Mulawarman \\ E-mail: lauwtunging@hotmail.com, zainal.ilmi@feb.unmul.ac.id ariesta.heksarini@feb.unmul.ac.id
}

Abstract: $\quad$ This study aims to determine the effect of workload and motivation on employee satisfaction and performance (a study in the employees of PT Gema Soerya Samodra). With good quality human resources, it is hoped that the company's performance will be better and optimal. But of course, to achieve optimal performance, we often encounter various obstacles so that sometimes the desired results are not achieved.

The population in this study were employees of PT Gema Soerya Samodra, the sample in this study were 40 employees. Methods of data collection are carried out by distributing questionnaires or questionnaires to respondents who become the research sample. This study uses data analysis tools, namely the validity and reliability tests, so this study uses the partial least square (PLS) analysis method. The tools used in data processing use the PLS Smart program. The results show that 1)Workload positive and significant effect on satisfaction, 2) Motivation positive and significant effect on satisfaction, 3) Workload positive and significant effect on performance, 4) Motivation has a positive and significant effect on performance, 5) satisfaction has a positive and significant effect on performance.

Keywords: $\quad$ Workload, Satisfaction, Motivation, Performance.

\section{Preliminary}

Employees are seen as an important company asset and need to be managed and developed in order to achieve company goals, because the success of a company cannot be separated from the role of employees in the organization. In running the company, employees are required to be able to perform in accordance with what the company expects.Priansa (2014: 269)argues that performance is not an individual characteristic, such as talent or ability, but is a manifestation of the talent or ability itself. With good quality human resources, it is hoped that the company's performance will be better and optimal. But of course, to achieve optimal performance, we often encounter various obstacles so that sometimes the desired results are not achieved.

Every employee in a company needs to get satisfaction at work which can also have an impact on improving employee performance, such asAffandi (2016: 33)which states that job satisfaction 
International Journal of Economics, Business and Accounting Research (IJEBAR)

Peer Reviewed - International Journal

Vol-4, Issue-3, 2020 (IJEBAR)

E-ISSN: 2614-1280 P-ISSN 2622-4771

https://jurnal.stie-aas.ac.id/index.php/IJEBAR

leads to increased performance, so that satisfied workers will be more productive at work. Likewise withWirawan (2013: 699)which states that people's positive or negative feelings and attitudes towards their work have an impact on themselves and the organization. If a person is satisfied with his job he likes and is motivated to do his job and has a high performance, on the other hand, if he is not satisfied with his job, he is not motivated to do his job and his performance is low. Meanwhile, according toRobbins \& Judge (2008: 107) Job satisfaction is a positive feeling about one's job which is the result of an evaluation of its characteristics.

One of the things that can cause the target not to be achieved is the workload that is too heavy, so that employees become unproductive. According toGibson \& Ivancevich (2009: 163)workload is pressure as a response that cannot adapt, which is influenced by individual differences or psychological processes, namely a consequence of any external action (environment, situation, event that makes too many psychological or physical demands) on a person. According toWibowo (2010: 33)workload is a competition from a limited mental resource. Apart from workload, motivation can also affect employee satisfaction and performance. According toWinardi (2016: 6) motivation is a potential force that exists within a human being, which he can develop on his own or be developed by a number of outside forces that can positively or negatively affect the results of his performance.

The formulation of the problem in this study is as follows:

1. Does workload affect employee satisfaction at PT Gema Soerya Samodra?

2. Does work motivation affect employee satisfaction at PT Gema Soerya Samodra?

3. Does the workload affect the employee performance of PT Gema Soerya Samodra?

4. Does work motivation affect the employee performance of PT Gema Soerya Samodra?

5. Does satisfaction affect the employee performance of PT Gema Soerya Samodra?

\section{Research methods}

This research is a survey research, where the data collection uses a questionnaire. A survey is a study that takes a sample from a population and is the main means of collecting data. The definition of survey is limited to the survey sample where a portion of the population is taken to represent the entire study. The population in this study were female and male employees who work at PT Gema Soerya Samodra.

The technique used in sampling in this study was to distribute questionnaires to 40 employees who worked at PT Gema Soerya Samodra. In this study, there are 18 indicators.

\section{Results and Discussion}

\subsection{Result}

Based on the answers given by the respondents in this study, it can be explained that some of the prescribing criteria are gender, age, education and length of work.

Table 3.1

Gender

\begin{tabular}{|c|c|c|c|}
\hline No. & Gender & total & Percentage \\
\hline 1. & Male & 35 & $\mathbf{8 7 . 5 \%}$ \\
\hline 2. & Women & 5 & $12.5 \%$ \\
\hline \multicolumn{2}{|c|}{ Total } & $\mathbf{4 0}$ & $\mathbf{1 0 0 \%}$ \\
\hline
\end{tabular}

Source: Author compiled, 2020

In table 3.1 above, it can be seen that of the 40 respondents, the dominant number of respondents was male respondents as many as 35 respondents. 
International Journal of Economics, Business and Accounting Research (IJEBAR)

Peer Reviewed - International Journal

Vol-4, Issue-3, 2020 (IJEBAR)

E-ISSN: 2614-1280 P-ISSN 2622-4771

https://jurnal.stie-aas.ac.id/index.php/IJEBAR

Table 3.2

Age

\begin{tabular}{|c|c|c|c|}
\hline No. & Age & total & Percentage \\
\hline 1. & 16-20 Years & 0 & $0 \%$ \\
\hline 2. & $21-25$ Years & 13 & $32.5 \%$ \\
\hline 3. & 26-30 Years & 17 & $42.5 \%$ \\
\hline 4. & $>31$ Years & 10 & $25 \%$ \\
\hline \multicolumn{2}{|c|}{ Total } & 40 & $100 \%$ \\
\hline
\end{tabular}

Source: Author compiled, 2020

In table 3.2 above, it can be seen that of the 40 respondents, the dominant number of respondents was respondents aged 26-30 years as many as 17 respondents.

Table 3.3

Last education

\begin{tabular}{|c|c|c|c|}
\hline No. & Last education & total & Percentage \\
\hline 1. & Junior High & 0 & $0 \%$ \\
\hline 2. & High school & 8 & $20 \%$ \\
\hline 3. & Diploma & 9 & $22.5 \%$ \\
\hline 4. & Bachelor & 23 & $57.5 \%$ \\
\hline & Total & 40 & $100 \%$ \\
\hline
\end{tabular}

Source: Author compiled, 2020

In table 3.3 above, it can be seen that of the 40 respondents, the dominant number of respondents was 23 respondents with a Bachelor's degree.

Table 3.4

Length of work

\begin{tabular}{|c|c|c|c|}
\hline No. & Length of work & total & Percentage \\
\hline 1. & $<1$ year & 8 & $20 \%$ \\
\hline 2. & 12 years old & 32 & $80 \%$ \\
\hline 3. & 35 years old & 0 & $0 \%$ \\
\hline 4. & $>5$ Years & 0 & $0 \%$ \\
\hline & Total & 40 & $100 \%$ \\
\hline
\end{tabular}

Source: Author compiled, 2020

In table 3.4 above, it can be seen that of the 40 respondents, the dominant number of respondents was 32 respondents with a length of work of 1 - 2 years.

\subsection{Discussion}

Validity and reliability are used to test instruments in the form of indicators and questions to meet the requirements or can be used as measurement variables. Following are the results of testing the validity and reliability of the test instrument using PLS with a sample of 40 respondents: 
International Journal of Economics, Business and Accounting Research (IJEBAR)

Peer Reviewed - International Journal

Vol-4, Issue-3, 2020 (IJEBAR)

E-ISSN: 2614-1280 P-ISSN 2622-4771

https://jurnal.stie-aas.ac.id/index.php/IJEBAR

Table 3.5

Outer Loading of Each Construct

\begin{tabular}{|c|c|c|c|}
\hline Variable & Indicator & Outer Loading & Value Limit \\
\hline Workload & X1.1 & 0.919 & 0.7 \\
\hline & X1.2 & 0.947 & 0.7 \\
\hline Motivation & X1.3 & 0.923 & 0.7 \\
\hline & X2.2 & 0.780 & 0.7 \\
\hline Satisfaction & X2.3 & 0.824 & 0.7 \\
\hline & Y1.1 & 0.871 & 0.7 \\
\hline & Y1.2 & 0.865 & 0.7 \\
\hline & Y1.3 & 0.844 & 0.7 \\
\hline & Y1.4 & 0.823 & 0.7 \\
\hline Yerformance & Y1.5 & 0.911 & 0.7 \\
\hline & Y2.1 & 0.853 & 0.7 \\
\hline & Y2.3 & 0.713 & 0.7 \\
\hline & Y2.4 & 0.945 & 0.7 \\
\hline & Y2.5 & 0.927 & 0.7 \\
\hline & Y2.6 & 0.897 & 0.7 \\
\hline & Y2.7 & 0.916 & 0.7 \\
\hline
\end{tabular}

Source: SmartPLS output

Based on table 3.5, it can be seen that the outer loading values all have values above 0.7 . This means that the indicator is declared to meet the convergent validity and is declared worthy or valid for use in research.

Table 3.6

Average Variance Extracted (AVE)

\begin{tabular}{|c|c|c|}
\hline & AVE & Information \\
\hline Workload & 0.864 & Valid \\
\hline Motivation & 0.682 & Valid \\
\hline Satisfaction & 0.739 & Valid \\
\hline Performance & 0.768 & Valid \\
\hline
\end{tabular}

Source: Primary data processed, 2020

In table 3.6, the average variance extracted shows a value above 0.50 , meaning that the instrument variable can be said to be a valid discriminant.

Table 3.7

Cronbach Alpha value

\begin{tabular}{|c|c|c|}
\hline & Cronbachs Alpha & Information \\
\hline Workload & 0.922 & Reliable \\
\hline Motivation & 0.768 & Reliable \\
\hline Satisfaction & 0.911 & Reliable \\
\hline Performance & 0.948 & Reliable \\
\hline
\end{tabular}

Source: Primary data processed, 2020 
International Journal of Economics, Business and Accounting Research (IJEBAR)

Peer Reviewed - International Journal

Vol-4, Issue-3, 2020 (IJEBAR)

E-ISSN: 2614-1280 P-ISSN 2622-4771

https://jurnal.stie-aas.ac.id/index.php/IJEBAR

From table 3.7 it can be seen that all Cronbach alpha values are above 0.6, which means that the four variables are reliable to become the model measuring variables. Besides that, it can also be seen from the composite reliability value.

Table 3.8

Composite Reliability

\begin{tabular}{|c|c|c|}
\hline & Composite Reliability & Information \\
\hline Workload & 0.950 & Reliable \\
\hline Motivation & 0.865 & Reliable \\
\hline Satisfaction & 0.934 & Reliable \\
\hline Performance & 0.958 & Reliable \\
\hline
\end{tabular}

Source: Primary data processed, 2020

Table 3.8 above shows that the instruments used for Workload, Motivation, Satisfaction, and Performance variables are reliable because the composite reliability value is $>0.70$, meaning that the instrument items have consistency as a construct measuring tool. So it can be concluded that the four latent variables are reliable because all indicator blocks are indeed a measure of their respective latent variables.

\section{Goodness of Fit Model Check}

Knowing the goodness-fit of the model can be seen from the R-Square value. The R-Square value can be used to explain the effect of the independent variable on the dependent variable having a substantive effect.

Table 3.9 R - Square

\begin{tabular}{|c|c|c|c|}
\hline No. & Variable & R Square & R Square Adjusted \\
\hline 1. & Satisfaction & 0.661 & 0.643 \\
\hline 2. & Performance & 0.807 & 0.791 \\
\hline
\end{tabular}

Source: Author compiled, 2020

Based on this table, it can be seen that satisfaction has an R-square value of 0.611 , which means that customer satisfaction can be explained by workload and motivation of $66.1 \%$. Meanwhile, the other $33.9 \%$ are explained by other variables outside the one under study. Furthermore, performance has an R-square value of 0.807 , which means that performance can be explained by workload, motivation and satisfaction of $80.7 \%$. While the other $19.3 \%$ were explained by other variables outside the one under study. 
International Journal of Economics, Business and Accounting Research (IJEBAR)

Peer Reviewed - International Journal

Vol-4, Issue-3, 2020 (IJEBAR)

E-ISSN: 2614-1280 P-ISSN 2622-4771

https://jurnal.stie-aas.ac.id/index.php/IJEBAR

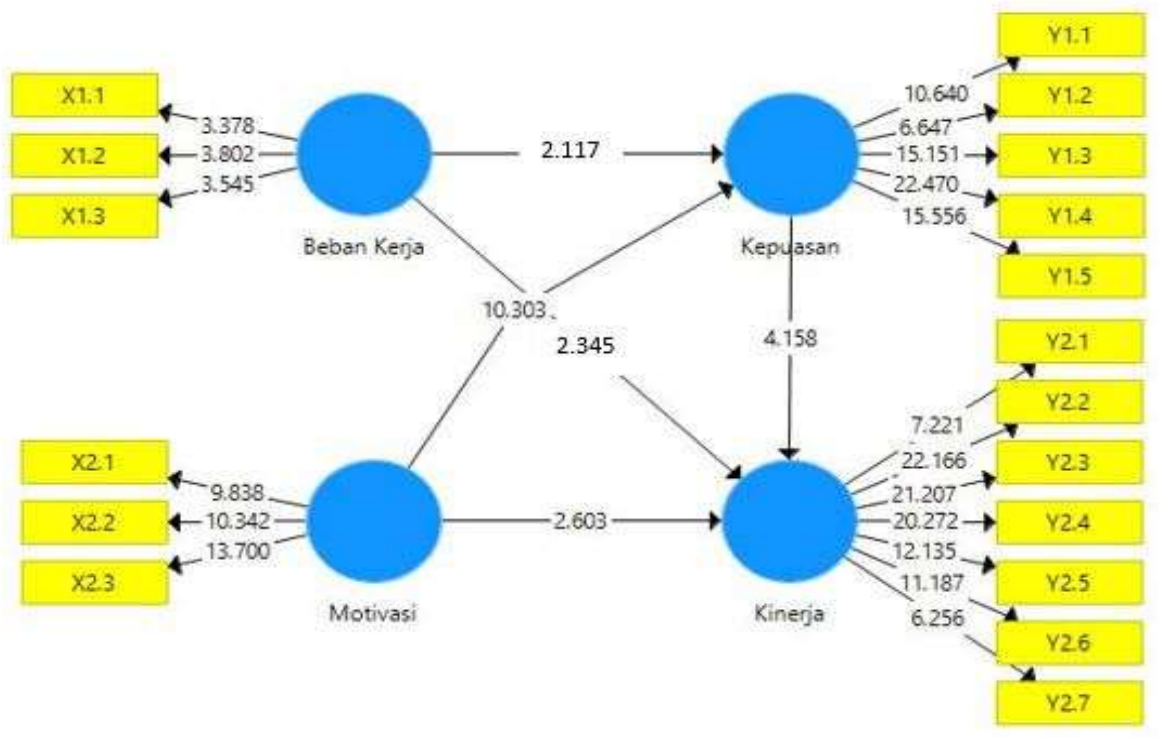

Figure 3.1

Bootstrapping Results

In the smartPLS application program, a t-test is carried out on each line. The test results can be seen in table 3.10 below:

Table 3.10

Path Coefficients

\begin{tabular}{|l|c|c|c|c|c|}
\hline & $\begin{array}{l}\text { Original } \\
\text { Sample }\end{array}$ & $\begin{array}{l}\text { Sample } \\
\text { Mean }\end{array}$ & $\begin{array}{l}\text { Standard } \\
\text { Deviation }\end{array}$ & $\begin{array}{l}\text { T- } \\
\text { Statistics }\end{array}$ & P Values \\
\hline $\begin{array}{l}\text { Workload } \rightarrow \\
\text { Satisfaction }\end{array}$ & -0.079 & -0.062 & 0.116 & 2,117 & 0.001 \\
\hline $\begin{array}{l}\text { Workload } \rightarrow \\
\text { Performance }\end{array}$ & -0.043 & -0.044 & 0.071 & 2,345 & 0.003 \\
\hline $\begin{array}{l}\text { Satisfaction } \rightarrow \\
\text { Performance }\end{array}$ & 0.592 & 0.576 & 0.142 & 4,158 & 0,000 \\
\hline $\begin{array}{l}\text { Motivation } \rightarrow \\
\text { Satisfaction }\end{array}$ & 0.810 & 0.807 & 0.079 & 10,303 & 0,000 \\
\hline $\begin{array}{l}\text { Motivation } \rightarrow \\
\text { Performance }\end{array}$ & 0.346 & 0.353 & 0.133 & 2,603 & 0.010 \\
\hline
\end{tabular}

Source: Primary data processed, 2020

With the hypotheses formulated in the previous chapter, the results of hypothesis testing in table 3.10 can be summarized as follows:

H1 : Stating that workload has a significant effect on satisfaction. The results of testing the hypothesis of the value of T-statistics are 2.117> 1.96, which means that the 
hypothesis which states that the workload has a significant effect on satisfaction is proven true or $\mathrm{H} 1$ is accepted.

$\mathrm{H} 2$ : Stating that motivation has a significant effect on satisfaction. Based on the results of hypothesis testing, it is known that motivation has a positive and significant effect on satisfaction with a T-statistical value of $10.303<1.96$. So that the results of this study are in accordance with the third hypothesis which states that motivation has a significant effect on satisfaction. Hypothesis 2 is accepted.

H3 : Stating that workload has a significant effect on performance. Based on the results of hypothesis testing, it is known that Workload has a negative and significant effect on performance with a T-statistical value of 2.345>1.96. So that the results of this study are in accordance with the second hypothesis which states that Workload has a significant effect on performance or hypothesis 3 is accepted.

H4 : Stating that motivation has a significant effect on performance. Based on the results of hypothesis testing, it is known that motivation has a positive and significant effect on performance with a T-statistical value of 2.603>1.96. So that the results of this study are in accordance with the fourth hypothesis which states that motivation has a significant effect on performance, proven true or hypothesis 4 is accepted.

H5 : Stating that satisfaction has a significant effect on performance. Based on the results of hypothesis testing, it is known that satisfaction has a positive and significant effect on performance with a T-statistical value of 4.158>1.96. So that the results of this study are in accordance with the fifth hypothesis which states that satisfaction has a significant effect on performance, proven true or hypothesis 5 is accepted.

\section{Conclusion}

Based on the results of the analysis and discussion of the research, some conclusions that can be drawn in this study are as follows:

1. Based on the results of hypothesis testing, it is known that workload has a negative and significant effect on satisfaction. These results mean that the higher the workload, the lower the satisfaction felt by employees of PT Gema Soerya Samodra, and vice versa. Thus hypothesis 1 which states that workload has a significant effect on satisfaction is accepted, $\mathrm{H} 1$ is accepted.

2. Based on the results of hypothesis testing, it is known that motivation has a positive and significant effect on satisfaction. These results mean that the higher the motivation, the higher the level of satisfaction felt by the employees of PT Gema Soerya Samodra. Thus hypothesis 2 which states that motivation has a significant effect on satisfaction is accepted, $\mathrm{H} 2$ is accepted.

3. Based on the results of hypothesis testing, it is known that workload has a negative and significant effect on performance. These results mean that the higher the workload, the lower the employee performance of PT Gema Soerya Samodra. Vice versa, the lower the workload, the higher the employee's performance. Thus hypothesis 3 which states that workload has a significant effect on performance is accepted, H3 is accepted.

4. Based on the results of hypothesis testing, it is known that motivation has a positive and significant effect on performance. These results mean that the higher the motivation, the 
International Journal of Economics, Business and Accounting Research (IJEBAR)

Peer Reviewed - International Journal

Vol-4, Issue-3, 2020 (IJEBAR)

E-ISSN: 2614-1280 P-ISSN 2622-4771

https://jurnal.stie-aas.ac.id/index.php/IJEBAR

higher the employee performance of PT Gema Soerya Samodra. Thus hypothesis 4 which states that motivation has a significant effect on performance is accepted, H4 is accepted.

5. Based on the results of hypothesis testing, it is known that satisfaction has a positive and significant effect on performance. These results mean that the higher the satisfaction, the higher the employee performance of PT Gema Soerya Samodra. Thus hypothesis 5 which states that satisfaction has a significant effect on performance is accepted, H5 is accepted.

\section{Suggestion}

The results of this study are expected to increase the development of science. Based on the results of the analysis, discussion, and conclusions in this study, the suggestions that can be given are as follows:

1. Recommended onPT Gema Soerya Samodra to reduce the workload experienced by employees in the form of excessive workloads or by increasing the number of employees so that the employee workload is reduced and employees can feel satisfied with their work.

2. It is recommended that PT Gema Soerya Samodra be able to maintain and even increase the motivation of employees in the company. One of the things that companies can do is to pay more attention to employees in the form of appreciation for employees who do their job well so that employees will feel happy and satisfied with the company.

3. It is recommended that PT Gema Soerya Samodra reduce the workload experienced by employees in the form of excessive workloads or by increasing the number of employees so that the workload of employees is reduced and employees can do their work optimally which of course will also affect the achievement of company targets.

4. Recommended toPT Gema Soerya Samodra to be able to maintain and even increase the motivation of employees in the company. One of the things that companies can do is to pay more attention to employees in the form of appreciation for employees who do their job well.

5. Recommended onPT Gema Soerya Samodra to be able to maintain and even increase the level of satisfaction that exists in the company. Companies must maintain comfortable and conducive working conditions for employees, because comfortable and conducive working conditions will certainly affect the performance of employees.

6. For the company to be able to maintain the variables that are considered good according to the perceptions of existing employees.

7. For further researchers, it is hoped that they can develop research with more or different variables than this study, and also be able to use a greater number of respondents to get even better results.

\section{References}

Affandi. (2016). Concept \& Indicator Human Resources Management for Management Research. CV Budi Utama.

Gibson, Ivancevich, Donnelly, \& Konopaske. (2009). Organizational Behavior. McGraw Hill. Priansa, DJ (2014). HR Planning \& Development. Alfabeta.

Robbins, SP, \& Judge, T.. (2008). Organizational behavior. Four Salemba.

Wibowo. (2010). Work management. Rajawali Press.

Winardi, J. (2016). Change management. Prenada Media Group.

Hero. (2013). Leadership: Theory, Psychology, Organizational Behavior, Applications and Research. PT Grafindo Persada. 